\title{
Endothelin-1 Is an Autocrine/Paracrine Factor in the Mechanism of Angiotensin II-induced Hypertrophy in Cultured Rat Cardiomyocytes
}

\author{
Hiroshi Ito, Yukio Hirata, Susumu Adachi, Masato Tanaka, Motoyoshi Tsujino, \\ Akira Koike, Akihiko Nogami, Fumiaki Marumo, and Michiaki Hiroe \\ Second Department of Internal Medicine, Tokyo Medical and Dental University, Tokyo 113, Japan
}

\section{Abstract}

To elucidate the cellular mechanism by which angiotensin II (ANG II) induces cardiac hypertrophy, we investigated the possible autocrine/paracrine role of endogenous endothelin-1 (ET-1) in ANG II-induced hypertrophy of neonatal rat cardiomyocytes by use of synthetic ET-1 receptor antagonist and antisense oligonucleotides to preproET-1 (ppET-1) mRNA. Northern blot analysis and in situ hybridization revealed that ppET-1 mRNA was expressed in cardiomyocytes, but, to a lesser extent, in nonmyocytes as well. ANG II upregulated ppET-1 mRNA level by threefold over control level as early as $30 \mathrm{~min}$, and it stimulated release of immunoreactive ET-1 from cardiomyocytes in a dose- and time-dependent manner. ET-1 stimulated ppET-1 mRNA levels after $30 \mathrm{~min}$ in a similar fashion as ANG II. Tetradecanoylphorbol-acetate $\left(10^{-7} \mathrm{M}\right) \mathrm{mim}$ icked the effects of ANG II and ET-1 on induction of ppET-1 mRNA. ANG II-induced ppET-1 gene expression was completely blocked by protein kinase $\mathrm{C}$ inhibitor $\mathrm{H}-7$ or by downregulation of endogenous protein kinase $\mathrm{C}$ by pretreatment with phorbol ester. ET-1 and ANG II stimulated twofold increase $\left[{ }^{3} \mathrm{H}\right]$ leucine incorporation into cardiomyocytes, whose effects were similarly and dose dependently inhibited by endothelin $A$ receptor antagonist (BQ123). Introduction of antisense sequence against coding region of ppET-1 mRNA into cardiomyocytes resulted in complete blockade with ppET-1 mRNA levels and $\left[{ }^{3} \mathbf{H}\right]$ leucine incorporation stimulated by ANG II. These results suggest that endogenous ET-1 locally generated and secreted by cardiomyocytes may contribute to ANG II-induced cardiac hypertrophy via an autocrine/paracrine fashion. (J. Clin. Invest. 1993. 92:398-403.) Key words: preproendothelin-1 mRNA - neonatal rat cardiomyocytes • endothelin A receptor antagonist $\bullet$ antisense nucleotides

\section{Introduction}

Endothelin-1 (ET-1 $)^{1}$ is a 21 -residue vasoconstrictor/vasopressor peptide originally characterized from the supernatant

Address correspondence and reprint requests to Hiroshi Ito, Second Department of Internal Medicine, Tokyo Medical and Dental University, 1-5-45 Yushima, Bunkyo-ku, Tokyo 113, Japan.

Received for publication 7 April 1992 and in revised form 3 February 1993.

1. Abbreviations used in this paper: ANG II, angiotensin II; Ara C, cytosine arabinoside; ET-1, endothelin-1;ET-1-LI, ET-1-like immunoreactivity; ETA, endothelin A; GADPH, glyceraldehyde-3-phosphate dehydrogenase; NMCs, nonmyocytes; PKC, protein kinase C; ppET-1, preproET-1; SSPE, $0.75 \mathrm{M} \mathrm{NaCl} / 0.05 \mathrm{M} \mathrm{NaH}_{2} \mathrm{PO}_{4} / 0.005 \mathrm{M}$ EDTA; TPA, 12-O-tetradecanoylphorbol-13-acetate.

J. Clin. Invest.

(C) The American Society for Clinical Investigation, Inc. 0021-9738/93/07/398/06 \$2.00

Volume 92, July 1993, 398-403 of cultured porcine aortic endothelial cells (1). This endothelium-derived vasoconstrictive peptide has also been found to be a growth factor in a variety of mammalian cells including vascular smooth muscle cells (2) and fibroblasts (3). We have recently demonstrated that ET-1 induces hypertrophy of cardiomyocytes in vitro, associated with the induction of muscle specific genes (myosin light chain 2, $\alpha$-actin, and troponin I) and a protooncogene (c- $f o s)(4)$. Other investigators have also shown that ET-1 is a potent growth factor for cardiomyocytes $(5,6)$. Therefore, it is suggested that ET-1 may play an important role in the pathogenesis of cardiac hypertrophy associated with various cardiovascular diseases.

ET-1 is produced not only by vascular endothelial cells, but also by a variety of nonendothelial cells, such as vascular smooth muscle cells (7), renal epithelial cells (8), glomerular mesangial cells (9), and certain cancer cell lines (10). It has recently been reported that preproET-1 (ppET-1) mRNA is detected in a variety of rat tissue including heart (11). However, no information has yet been available whether ET-1 is produced by cardiomyocytes and acts by themselves in an autocrine and/or paracrine manner.

Angiotensin II (ANG II), on the other hand, is a potent vasoconstrictor hormone that is also involved in cardiac hypertrophy in vitro (12) as well as in vivo (13). To elucidate whether endogenous ET-1 is involved in the mechanism by which ANG II induces cardiac hypertrophy, we investigated the possible autocrine/paracrine role of ET-1 in ANG II-induced hypertrophy by use of a synthetic endothelin A (ETA) receptor antagonist and antisense oligonucleotides to ppET-1 mRNA in cultured neonatal rat cardiomyocytes.

\section{Methods}

Drugs and cDNAs. The following drugs were used: synthetic ET-1, angiotensin II (ANG II) (Peptide Institute, Osaka, Japan), 12-O-tetradecanoylphorbol-13-acetate (TPA), cytosine arabinoside (Ara C) (Sigma Immunochemicals, St. Louis, MO), 1-(5-isoqinolinylsulfonyl2-methylpiperazine (H-7) (Seikagaku Kogyo Co., Tokyo), deoxycytidine $5^{\prime}-\left[\alpha{ }^{32} \mathrm{P}\right]$ triphosphate, and $\left[{ }^{3} \mathrm{H}\right]$ leucine, (Amersham, Japan, Tokyo). BQ123 (14) and DuP753 (15) were provided by Banyu Pharmaceutical Co. Ltd. (Tokyo). cDNA for rat preproendothelin-1 (ppET-1) and glyceraldehyde-3-phosphate dehydrogenase (GAPDH) used for probes were generously provided by Dr. T. Masaki (Kyoto University, Kyoto, Japan) and Dr. K. Webster (SRI International, Menlo Park, CA), respectively.

Cell culture. Primary culture of neonatal rat cardiomyocytes was prepared by the method originally described by Simpson (16) with minor modifications (17). Briefly, the hearts from 1- or 2-d-old Wistar rats (Japan Laboratory Animals, Tokyo) were minced and dissociated with $0.1 \%$ trypsin. After dispersed cells were incubated on $100-\mathrm{mm}$ culture dishes (Falcon Labware, Becton Dickinson \& Co., Oxnard, CA) for $60 \mathrm{~min}$ at $37^{\circ} \mathrm{C}$ in $5 \% \mathrm{CO}_{2}$ incubator, nonattached viable cells were collected and seeded into $60-\mathrm{mm}$ dishes $\left(2 \times 10^{6} \mathrm{cells} / \mathrm{dish}\right)$ or 24-well plates $\left(0.5 \times 10^{6}\right.$ cells $/$ well $)$. In certain experiments, we prepared cultures of almost pure cardiomyocytes by use of cytosine arabinoside $\left(10^{-5} \mathrm{M}, 48 \mathrm{~h}\right)$, which preferentially reduces the proportion of nonmyocytes (NMCs) (17). Cultures of nonmyocytes were prepared 
as described (17). Cells were incubated in MEM supplemented with $5 \%$ calf serum for $48 \mathrm{~h}$ and then replaced with MEM plus $1 \%$ serum 24 $h$ before experiments. To downregulate endogenous protein kinase $C$ (PKC), cardiomyocytes were pretreated with $10^{-7} \mathrm{M}$ TPA for $24 \mathrm{~h}$ before exposure to ANG II.

Northern blot analysis. Total RNA of neonatal rat cardiomyocytes was isolated by guanidine thiocyanate and centrifuged through a $5.7 \mathrm{M}$ $\mathrm{CsCl}$ cushion (18). RNA was size-fractionated through a $1.4 \%$ agarose gel in $0.7 \mathrm{M}$ formaldehyde and $20 \mathrm{mM}$ morpholinopropanesulfonic acid $/ 5 \mathrm{mM}$ sodium acetate/ $1 \mathrm{mM}$ EDTA. Northern blot hybridization were performed with the hybridization buffer containing 50\% formamide, $5 \times$ Denhardt's solution, $100 \mu \mathrm{g} / \mathrm{ml}$ salmon sperm DNA, and $5 \times \operatorname{SSPE}\left(0.75 \mathrm{M} \mathrm{NaCl} / 0.05 \mathrm{M} \mathrm{NaH}_{2} \mathrm{PO}_{4} / 0.005 \mathrm{M}\right.$ EDTA $) .{ }^{32} \mathrm{P}$ labeled cDNA probes were prepared by the random primer method (19). The membranes (Magnagraph nylon; Micron Separations Inc., Westborough, MA) were washed twice with $5 \times$ SSPE/10\% SDS at room temperature, twice with $1 \times$ SSPE/ $10 \%$ SDS, and once with $0.1 \times$ SSPE $/ 10 \%$ SDS at $37^{\circ} \mathrm{C}$ for 15 min each. If the background radioactivity remained high, further washing was performed with $0.1 \times$ SSPE/

$10 \% \mathrm{SDS}$ at $60^{\circ} \mathrm{C}$ for $15 \mathrm{~min}$. Autoradiography was performed on a Fuji RX film with an intensifying screen at $-80^{\circ} \mathrm{C}$. Autoradiograms were quantitated by densitometry (model GS 370; Hoefer Scientific Instruments, San Francisco, CA). Results were normalized to GAPDH expression.

In situ hybridization. Antisense and sense single-strand cRNAs were synthesized from cDNA fragment encoding rat ppET-1 subcloned into pBluescript II (Stratagene, La Jolla, CA) in the presence of digoxigenin labeled UTP (Boehringer Mannheim Biochemicals, Indianapolis, IN). The cardiomyocytes plated (Tissue Culture Chambers; Nunc Inc., Roskilde, Denmark) were fixed in 4\% parafor-

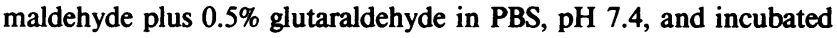
with proteinase $\mathrm{K}(100 \mu \mathrm{g} / \mathrm{ml}$, Boehringer Mannheim Biochemicals) in $100 \mathrm{mM}$ Tris $\mathrm{HCl}, \mathrm{pH} 7.6$, for $10 \mathrm{~min}$ at room temperature. The hybridization buffer contained $0.6 \mathrm{M} \mathrm{NaCl}, 1 \mathrm{mM}$ EDTA, $10 \mathrm{mM}$ Tris $\mathrm{HCl}, \mathrm{pH} 7.6,10 \%$ dextran sulfate, $0.25 \% \mathrm{SDS}, 100 \mu \mathrm{g} / \mathrm{ml}$ transfer RNA, $1 \times$ Denhardt's solution, $50 \%$ ( vol/vol) deionized formamide, and labeled denatured probe. Hybridization buffer was applied to each section, followed by incubation in a moist chamber for $16 \mathrm{~h}$ at $50^{\circ} \mathrm{C}$. Samples were then incubated with $20 \mu \mathrm{g} / \mathrm{ml}$ RNase A (Boehringer Mannheim Biochemicals) for $30 \mathrm{~min}$ at $37^{\circ} \mathrm{C}$, followed by washing once with $2 \times \mathrm{SSC}$ plus $50 \%$ formamide for $30 \mathrm{~min}$ at $50^{\circ} \mathrm{C}$, and twice with $0.2 \times \mathrm{SSC}$ for $30 \mathrm{~min}$ at $50^{\circ} \mathrm{C}$. For immunological detection, DIG Nucleicacid Detection Kit from Boehringer Mannheim Biochemicals was used.

$R I A$. ET-1-like immunoreactivity (ET-1-LI) in media was determined by specific RIA for ET-1 as recently reported (20). The polyclonal antibody used cross-reacted fully with ET-1, $2 \%$ with big ET-1, and less than $0.1 \%$ with ET-2 and ET-3. In brief, $0.1 \mathrm{ml}$ standard and sample and $0.1 \mathrm{ml}$ antibody (final dilution, $1: 150,000$ ) were preincubated at $4^{\circ} \mathrm{C}$ for $24 \mathrm{~h}$, followed by the addition of $0.1 \mathrm{ml}$ [ ${ }^{125} \mathrm{I}$ ]ET-1 (specific activity: 2,000 Ci/mmol) (Amersham Japan) and further incubated for $48 \mathrm{~h}$. Separation of the bound from free ligand was accomplished by the double antibody method. The sensitivity of ET-1 RIA was $1 \mathrm{fmol} /$ tube, and the $50 \%$ intercept was $14 \mathrm{fmol} /$ tube. The intra- and interassay coefficients of variations were 6.9 and $7.3 \%$, respectively. Release of ET-1-LI was expressed as fixed number of cardiomyocytes $\left(10^{6}\right.$ cells $)$ as measured by Coulter counter (Coulter Corp., Hialeah, FL).

Incorporation of $\left[{ }^{3} \mathrm{H}\right]$ leucine. Protein synthesis by cardiomyocytes was evaluated by incorporation of $\left[{ }^{3} \mathrm{H}\right]$ leucine into cells as reported (4). Cardiomyocytes $\left(2 \times 10^{5}\right.$ cells $)$ were incubated with or without test compounds for $20 \mathrm{~h}$ in the medium supplemented with $1 \%$ calf serum and further incubated for $4 \mathrm{~h}$ with $0.5 \mu \mathrm{Ci}\left[{ }^{3} \mathrm{H}\right]$ leucine. At the end of labeling, cultures were rinsed three times with ice-cold PBS, and incubated with 5\% TCA on ice for $20 \mathrm{~min}$. After the cells were washed twice with ice-cold 5\% TCA, they were solubilized in $0.5 \mathrm{~N} \mathrm{NaOH}$. An aliquot of TCA-insoluble materials was neutralized and radioactivity was determined by a liquid scintillation counter (model 460CD; Packard Instrument Co., Inc., Meriden, $\mathrm{CO}$ ).

Antisense oligonucleotides. Antisense oligonucleotides against the first 15 nucleotides of the coding region of rat ppET-1 including AUG codon ( 3 TACCTAATAAAAGGG5') were synthesized by a DNA synthesizer (model 391; Applied Biosystems, Tokyo) and purified over a OPC column (Applied Biosystems). Mismatch oligonucleotides at three nucleotides ( 3 TACTTAATACAATGG5') were similarly synthesized. Cells were incubated with antisense or mismatch oligonucleotides for $24 \mathrm{~h}$ before treatment with ANG II.

Statistical analyses. One-way ANOVA and multiple comparison methods by Scheffe were used for statistical analyses. $P<0.05$ was considered significant.

\section{Results}

As shown in Fig. 1, abundant amount of ppET-1 mRNA was detected in cultured neonatal rat cardiomyocytes incubated with MEM for $24 \mathrm{~h}$. ANG II $\left(10^{-6} \mathrm{M}\right)$ upregulated ppET-1 mRNA level by approximately threefold over control level as early as $30 \mathrm{~min}$. ppET-1 gene expression then returned to basal level after $2 \mathrm{~h}$ and remained constant during $24 \mathrm{~h}$. ET-1 ( $10^{-7}$ $M)$ also transiently increased the expression of ppET-1 in a similar fashion as ANG II. TPA $\left(10^{-7} \mathrm{M}\right)$ mimicked the effects of ANG II and ET-1 on induction of ppET-1 mRNA. To ascertain that cardiomyocytes indeed express ppET-1 mRNA, we performed in situ hybridization using digoxigenin-labeled cRNA sense and antisense probe for ppET-1. The antisenseprobe for ppET-1 strongly hybridized with cardiomyocytes and with NMCs as well (Fig. 2). Northern blot analysis using cultures of Ara C-treated cardiomyocytes and NMCs revealed that ppET-1 mRNA level in NMCs was lower than that in cardiomyocytes (Fig. 3).

ANG II $\left(10^{-6} \mathrm{M}\right)$ stimulated ET-1-LI release from cardiomyocytes as early as $60 \mathrm{~min}$ and further increased during $24 \mathrm{~h}$ (Fig. $4 \mathrm{~A}$ ). ANG II dose dependently $\left(10^{-8} \mathrm{M}-10^{-6} \mathrm{M}\right)$ stimulated ET-1-LI release during $24 \mathrm{~h}$-incubation (Fig. $4 \mathrm{~B}$ ).

The ANG II-induced ppET-1 gene expression was completely blocked by a PKC inhibitor H-7 $\left(10^{-5} \mathrm{M}\right)$, or by down-

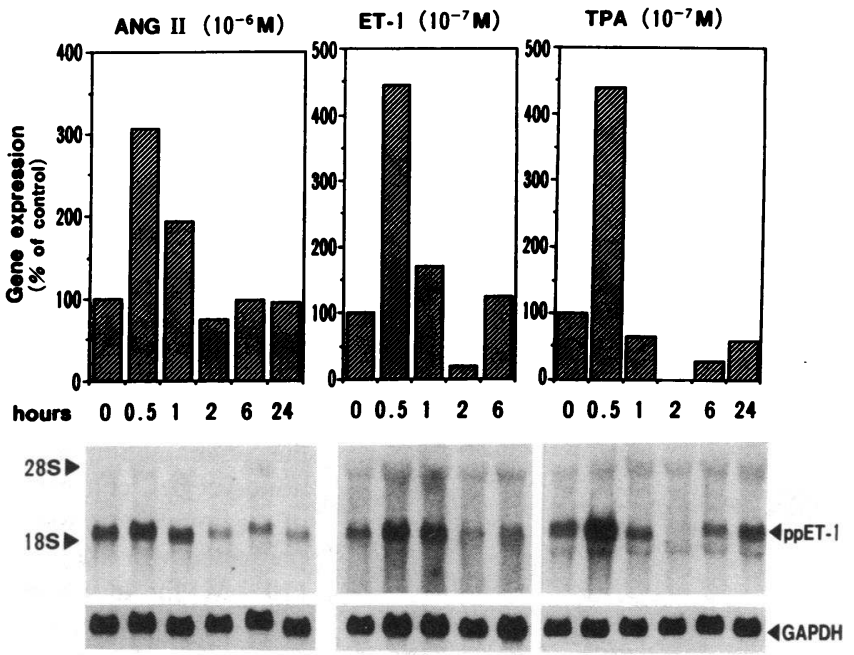

Figure 1. Induction of ppET-1 mRNA by ANG II, ET-1, and TPA as a function of time. Neonatal rat cardiomyocytes were exposed to ANG II $\left(10^{-6} \mathrm{M}\right)$, ET-1 $\left(10^{-7} \mathrm{M}\right)$, or TPA $\left(10^{-7} \mathrm{M}\right)$ for indicated times. Northern blot hybridization ( $7 \mu \mathrm{g}$ of total RNA/each lane) were performed using ${ }^{32} \mathrm{P}$-labeled rat ppET-1 or GAPDH cDNA as probes. Exposure time: 72 to $120 \mathrm{~h}$ for ppET-1 and $24 \mathrm{~h}$ for GAPDH. The autoradiograms were quantitated by densitometry, and the transcript levels are shown at the top. 


\section{Sense}

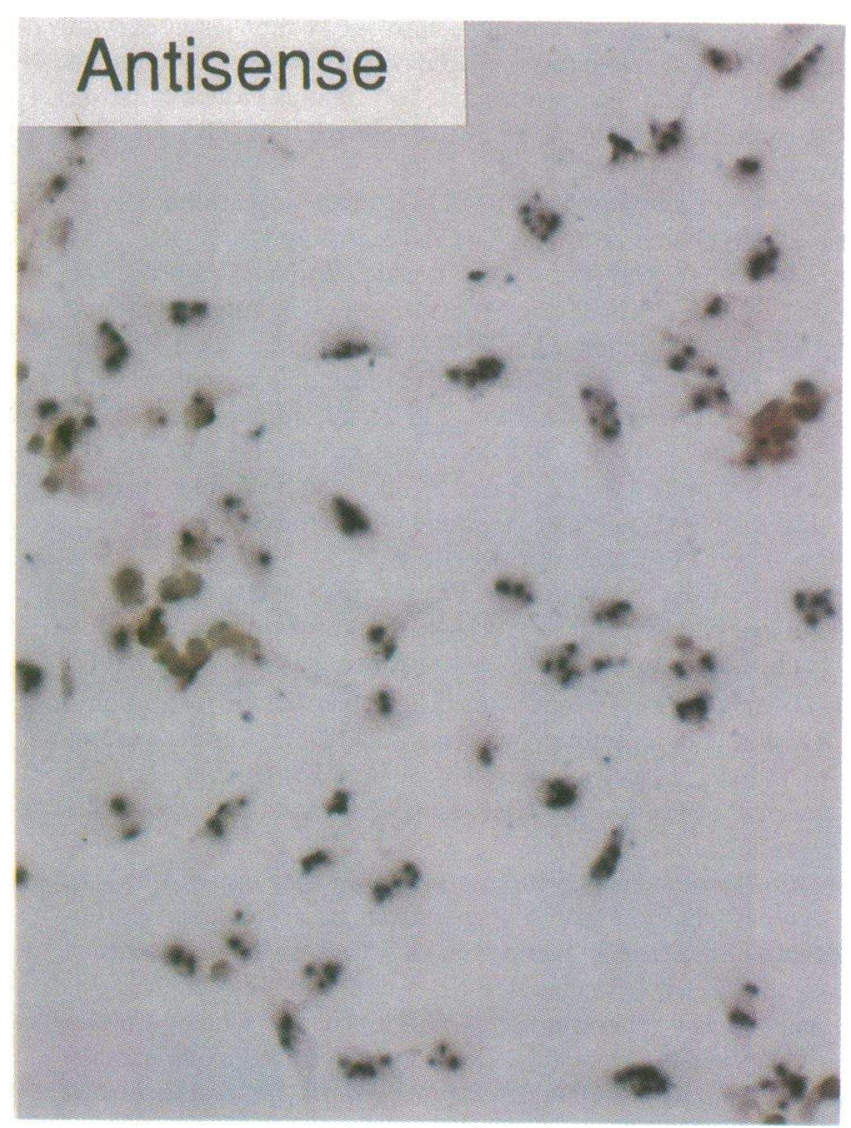

Figure 2. The light micrographs of in situ hybridization on cultured rat cardiomyocytes. The cells were hybridized with sense (left panel) and antisense (right panel) cRNA probes for ppET-1. Note the positive staining with antisense probe and the negative staining with sense probe used as control. $\times 200$.

regulation of endogenous PKC by pretreatment with TPA $\left(10^{-7} \mathrm{M}\right)$ (Fig. 5).

We next examined the effects of ETA receptor antagonist (BQ123) on ppET-1 mRNA levels stimulated by ET-1 and ANG II. The ET-1-stimulated ppET-1 gene expression was completely blocked by BQ123 $\left(10^{-5} \mathrm{M}\right)$, whereas ANG II-induced expression of ppET-1 was unaffected by BQ123 (Fig. 6). The effects of BQ123 on ET-1- and ANG II-induced protein synthesis in rat cardiomyocytes were then examined (Fig. 7). Both ET-1 $\left(10^{-8} \mathrm{M}\right)$ and ANG II $\left(10^{-7} \mathrm{M}\right)$ stimulated



Figure 3. ppET-1 mRNA levels in cardiomyocytes and nonmyocytes. To eliminate the contamination of nonmyocytes, cultures of cardiomyocytes were pretreated with Ara C $\left(10^{-5} \mathrm{M}\right)$ for $48 \mathrm{~h}$. Cultures of nonmyocytes were prepared as described in the text. Northern blot hybridization ( $7 \mu \mathrm{g}$ of total RNA/each lane) was performed as in Fig. 1. Exposure time: $120 \mathrm{~h}$ for ppET-1 and $24 \mathrm{~h}$ for GAPDH.
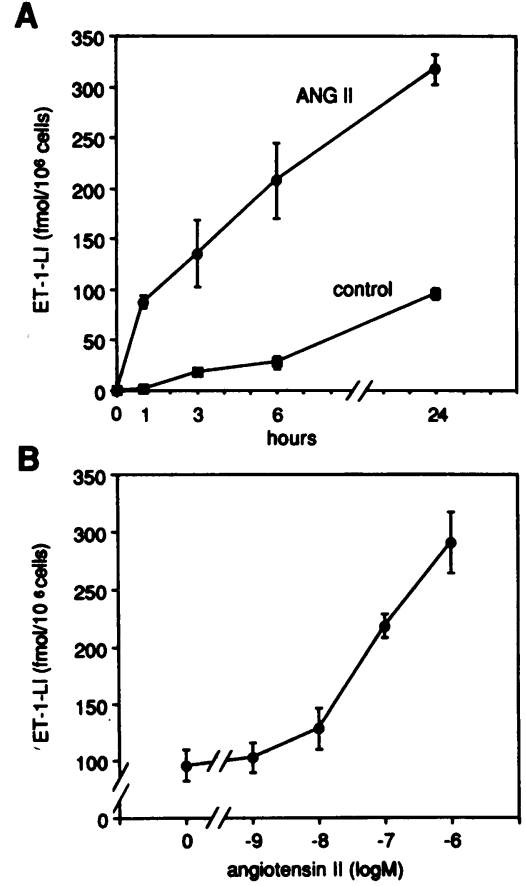

Figure 4. Effect of ANG II on release of immunoreactive ET-1 from cultured rat cardiomyocytes. $(A)$ Time course: Cells were treated with $(\bullet)$ or without (ø) ANG II $\left(10^{-7} \mathrm{M}\right)$ for indicated times. $(B)$ Dose response: Cells were treated with a variety of dose $\left(10^{-9}-10^{-6} \mathrm{M}\right)$ of ANG II for $24 \mathrm{~h}$. ET-1LI was measured by RIA. Each point represents mean of four experiments; bars show SEM. 


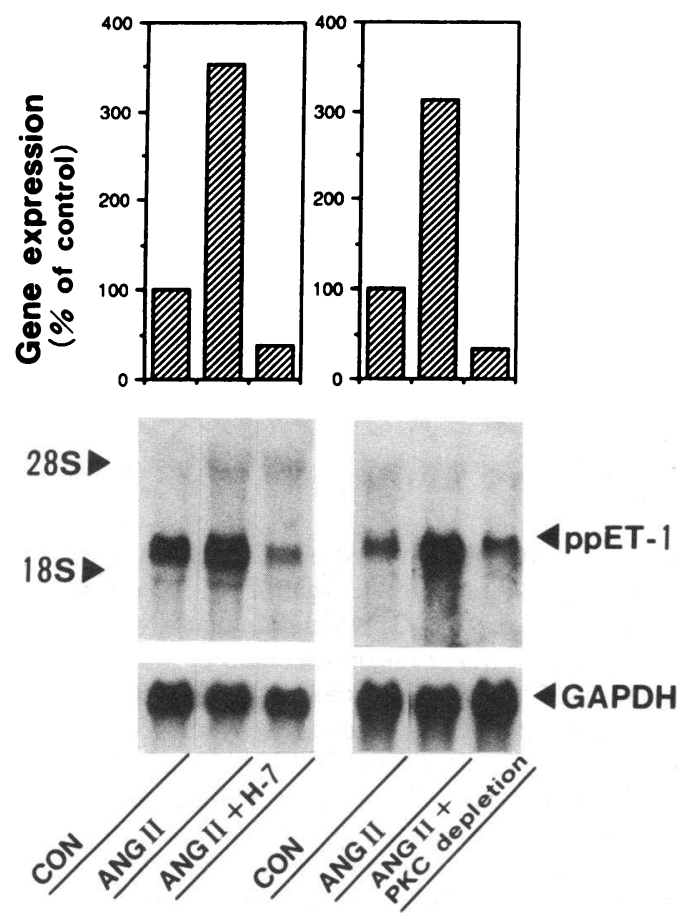

Figure 5. Effect of PKC inhibitor and depletion of endogenous PKC on ANG II-stimulated ppET-1 mRNA. Neonatal rat cardiomyocytes in culture were treated with ANG II $\left(10^{-6} \mathrm{M}\right)$ in the presence and absence of $\mathrm{H}-7$ ( $\left.10^{-5} \mathrm{M}\right)$ for $30 \mathrm{~min}$. To deplete endogenous PKC, cells were pretreated with TPA $\left(10^{-7} \mathrm{M}\right)$ for $24 \mathrm{~h}$ before exposure to ANG II for $30 \mathrm{~min}$. Northern blot hybridization ( $7 \mu \mathrm{g}$ of total RNA/each lane) was performed as in Fig. 1. Exposure time: $120 \mathrm{~h}$ for ppET-1 and $24 \mathrm{~h}$ for GAPDH. The transcript levels as quantitated by densitometry are shown at the top.

$\left[{ }^{3} \mathrm{H}\right]$ leucine uptake by twofold over control level, whose effects were dose dependently $\left(10^{-6}-10^{-5} \mathrm{M}\right)$ inhibited by $\mathrm{BQ} 123$, while BQ123 $\left(10^{-5} \mathrm{M}\right)$ alone had no effect on basal $\left[{ }^{3} \mathrm{H}\right]$ leucine uptake. The ET-1-induced $\left[{ }^{3} \mathrm{H}\right]$ leucine uptake was unaffected by ANG II receptor antagonist DuP753 $\left(10^{-6}\right.$ M), whereas DuP753 completely blocked ANG II-stimulated $\left[{ }^{3} \mathrm{H}\right]$ leucine incorporation (Table I).

To further determine the possible involvement of endogenous ET-1 in ANG II-induced hypertrophy, we introduced antisense oligonucleotides against coding region of ppET-1 mRNA in rat cardiomyocytes and examined the ppET-1 mRNA expression and protein synthesis stimulated by ANG II. The antisense sequence $\left(10^{-5} \mathrm{M}\right)$ blocked ppET-1 mRNA (Fig. $8 \mathrm{~A}$ ) and inhibited the ANG II-induced $\left[{ }^{3} \mathrm{H}\right]$ leucine incorporation ( Fig. $8 B$ ). The mismatch sequence have any effect on neither ANG II-induced ppET-1 mRNA nor protein synthesis.

\section{Discussion}

We have recently demonstrated that ET-1 induces hypertrophy in cultured rat cardiomyocytes associated with increases in DNA and protein syntheses (4). This hypertrophic effect was accompanied by increased transcriptional activation in muscle specific genes and the c-fos protooncogene, with a concomitant increase in phosphoinositide hydrolysis. Further, both PKC activator TPA and $\mathrm{Ca}^{2+}$ ionophore ionomycin mimicked this hypertrophic effect on cardiomyocytes in vitro. These ob-
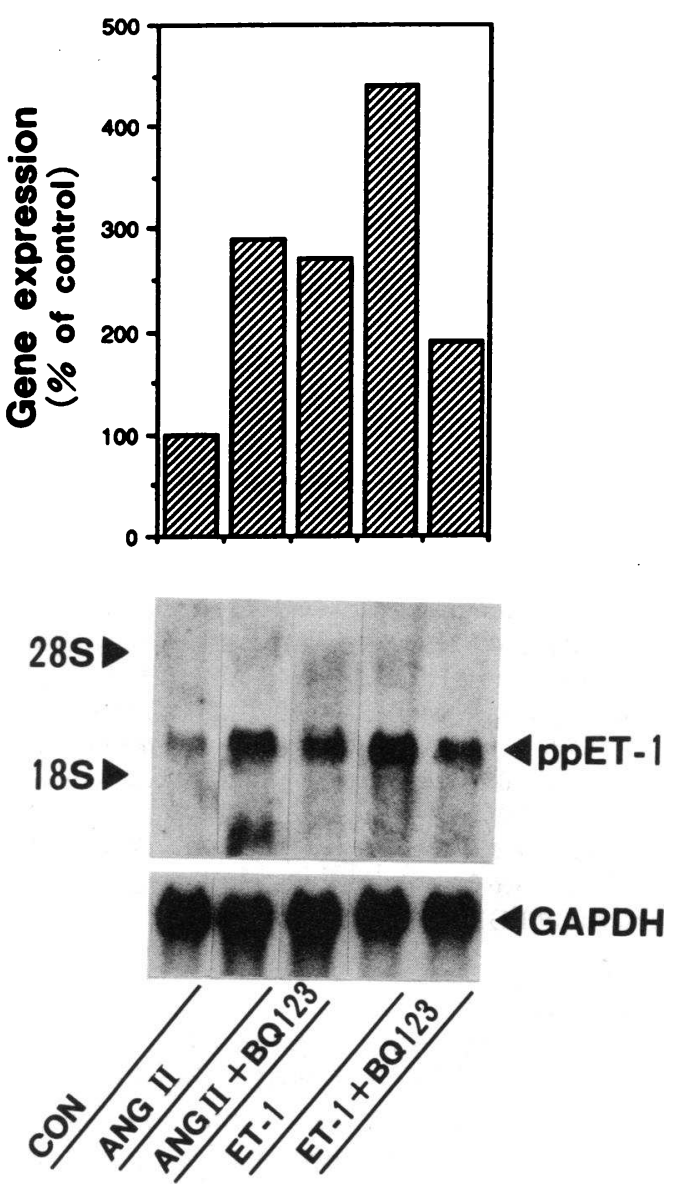

Figure 6. Effect of ETA receptor antagonist (BQ123) on ppET-1 mRNA stimulated by ANG II and ET-1 in cultured rat cardiomyocytes. Cells were pretreated with BQ123 $\left(10^{-5} \mathrm{M}\right)$ for $1 \mathrm{~h}$, followed by the treatment with ANG II $\left(10^{-6} \mathrm{M}\right)$ or ET-1 $\left(10^{-7} \mathrm{M}\right)$ for $30 \mathrm{~min}$. Northern blot hybridization ( $7 \mu \mathrm{g}$ of total RNA/each lane) were performed as indicated in Fig. 1. Exposure time: $120 \mathrm{~h}$ for ppET-1 and $24 \mathrm{~h}$ for GAPDH. The transcript levels as quantitated by densitometry are shown at the top.

servations led us to speculate that ET-1 may be involved in the development of cardiac hypertrophy, possibly through the activation of PKC and/or $\mathrm{Ca}^{2+}$ mobilization resulting from receptor-mediated phosphoinositide breakdown in cardiomyocytes.

Although ET-1 was originally characterized from the conditioned medium of cultured porcine aortic endothelial cells, recent evidence has revealed that ppET-1 mRNA expression as well as ET- 1 is widely distributed in a variety of nonendothelial cells $(7-21)$. The present study demonstrated for the first time that ppET-1 mRNA is abundantly expressed in neonatal rat cardiomyocytes, and ET-1-LI is released into media. These findings verify de novo synthesis and release of ET-1 by cardiomyocytes. Our primary cultures consist mainly of cardiomyocytes, although they contain $\sim 20 \%$ of NMCs. However, our results by Northern blot analysis that ppET-1 mRNA level in NMCs was lower than that in Ara C-treated cardiomyocytes suggest that the expression of ppET-1 mRNA and synthesis and release of ET-1 in our cultures represent mainly the properties of cardiomyocytes.

Genomic cloning of ppET-1 gene (22) has shown that the 5 -flanking region of ppET-1 gene contained the octanucleotide consensus sequences, called TPA-responsive element 


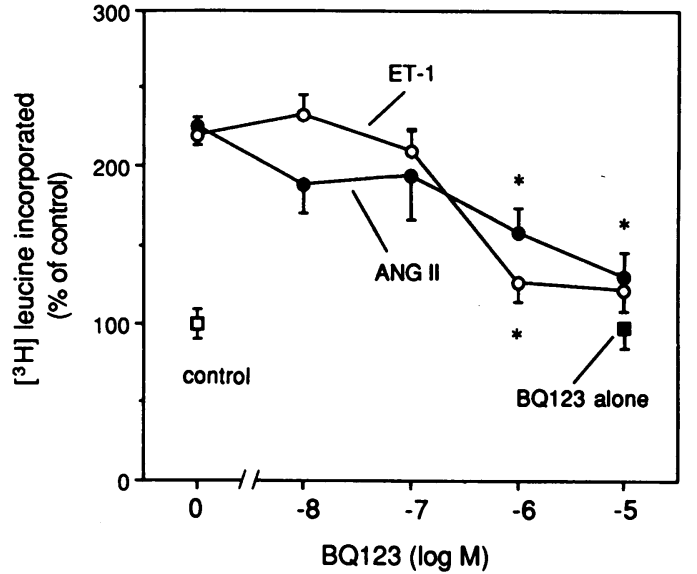

Figure 7. Effect of ETA receptor antagonist (BQ123) on protein synthesis stimulated by ET-1 and ANG II in cultured rat cardiomyocytes. Cells were pretreated with various concentrations of $\mathrm{BQ} 123\left(10^{-8}\right.$ $\left.10^{-5} \mathrm{M}\right)$ for $2 \mathrm{~h}$, and incubated with ET-1 $\left(10^{-8} \mathrm{M}\right)(\mathrm{O})$ and ANG II $\left(10^{-7} \mathrm{M}\right)(\bullet)$ for $24 \mathrm{~h}$. Control cells without any treatment $(\square)$ and with BQ123 $\left(10^{-5} \mathrm{M}\right)$ alone $(\square)$ are shown. Protein synthesis was assessed by incorporation of $\left[{ }^{3} \mathrm{H}\right]$ leucine into the cells. Each point represents mean of three to four experiments; bars show SEM. *Statistically significant difference from the cells stimulated by ET-1 and ANG II in the absence of BQ123 $(P<0.05)$.

(TRE) (also called APL-responsive element) (23). These cisacting sequences has been shown to be the binding sites for the complex of the proto-oncogene products c-jun and c-fos (24) and play an important role in the regulation of cell growth and oncogenesis in a variety of mammalian cells. c- fos mRNA level in cardiomyocytes has been shown to be upregulated by ET-1 (4) and ANG II (25) presumably via the activation of PKC and/or intracellular $\mathrm{Ca}^{2+}$ mobilization, suggesting the possible contribution of $\mathrm{c}$-fos to the development of cardiac hypertrophy. The present data that PKC inhibitor (H-7), as well as depletion of endogenous PKC by TPA, blocked the stimulatory effect of ANG II on ppET-1 gene expression also support the contribution of PKC in the transcriptional regulation of ppET-1. Thus, the activation of c-fos protooncogene products, after complex formation with c-jun products and binding to TPA-responsive element, might be involved in the mechanism of upregulation of ppET-1 gene transcription in cardiomyocytes. An immediate induction (within $30 \mathrm{~min}$ ) of ppET-1 mRNA levels by ANG II, ET-1 and TPA and subsequent decline to the basal levels ( $120 \mathrm{~min}$ ) by cardiomyocytes as observed in this study appears to be similar to that of vascu-

Table I. Effect of ANG II Receptor Antagonist Dup753 on ANG II or ET-1-induced Protein Synthesis in Cultured Rat Cardiomyocytes

\begin{tabular}{ll}
\hline & $\begin{array}{c}{\left[^{3} \mathrm{H}\right] \text { leucine incorporated }} \\
\text { (\% of control) }\end{array}$ \\
\hline Control & $100.0 \pm 14.0$ \\
ANG II $\left(10^{-7} \mathrm{M}\right)$ & $173.8 \pm 18.7^{*}$ \\
ANG II $\left(10^{-7} \mathrm{M}\right)+\operatorname{Dup} 753\left(10^{-6} \mathrm{M}\right)$ & $114.0 \pm 6.6$ \\
ET-1 $\left(10^{-8} \mathrm{M}\right)$ & $181.0 \pm 1.1^{*}$ \\
ET-1 $\left(10^{-8} \mathrm{M}\right)+\operatorname{Dup} 753\left(10^{-6} \mathrm{M}\right)$ & $164.3 \pm 8.7^{*}$ \\
\hline
\end{tabular}

Each value is mean $\pm \operatorname{SEM}(n=4) .{ }^{*} P<0.05$ vs control.
A

B

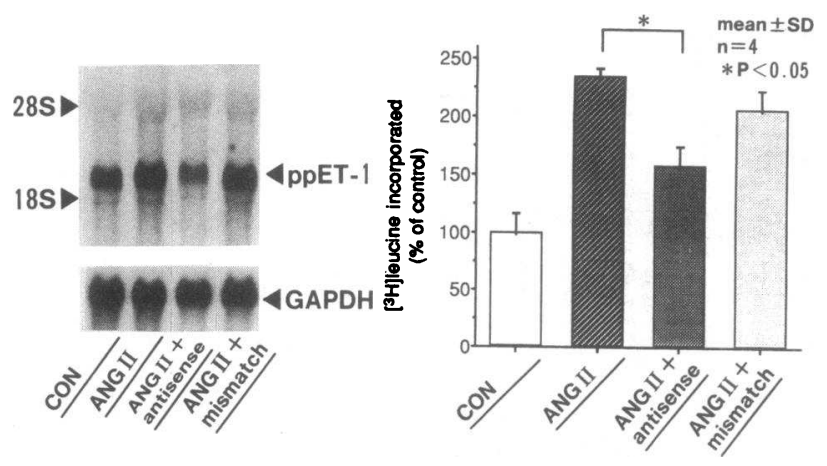

Figure 8. Inhibition of ANG II-stimulated ppET-1 mRNA and protein synthesis by antisense origonucleotides against ppET-1 mRNA in cultured rat cardiomyocytes. $(A)$ Cells were pretreated with antisense oligonucleotides $\left(10^{-5} \mathrm{M}\right)$ or oligonucleotides of mismatch sequence $\left(10^{-5} \mathrm{M}\right)$ for $24 \mathrm{~h}$, followed by exposure to ANG II $\left(10^{-6}\right.$ M) for $30 \mathrm{~min}$. Northern blot hybridization ( $7 \mu \mathrm{g}$ of total RNA/each lane) were performed as in Fig. 1. Exposure time: $120 \mathrm{~h}$ for ET-1 and $24 \mathrm{~h}$ for GAPDH. $(B)$ Cells were pretreated with antisense oligonucleotides $\left(10^{-5} \mathrm{M}\right)$ or oligonucleotides of mismatch sequence $\left(10^{-5} \mathrm{M}\right)$ for $24 \mathrm{~h}$, followed by exposure to ANG II $\left(10^{-6} \mathrm{M}\right)$ for 24 $h$. Synthesis of protein was assessed by incorporation of $\left[{ }^{3} \mathrm{H}\right]$ leucine into the cells. Each column represents mean of four experiments; bars show SD. *Statistically significant difference from the cells stimulated cells by ANG II alone $(P<0.05)$.

lar endothelial cells $(26,27)$. Such high turnover of ppET-1 transcripts is caused by short intracellular half-life (within 15 min) (26). Indeed, human ppET-1 gene contains several AUUUA motifs in the 3 '-untranslating regions (22) responsible for destabilizing mRNA.

Rapid induction of ppET-1 mRNA was followed by release of ET-1-LI in culture medium, whereas, it continued to increase up to $24 \mathrm{~h}$. This sustained increase in ET-1 into culture medium was in agreement with our previous study using bovine endothelial cells (28), and may be explained by the following reasons: First, it has been suggested that cell-mediated degradation and/or inactivation of ET-1 may occur little, if any, during incubation with cultured cells (29). Second, a constitutive pathway of ET-1 secretion by endothelial cells was suggested based on the observation that endothelial cells contain no secretory granules within their cytoplasm.

In the present study, a selective ETA receptor antagonist (BQ123) inhibited protein synthesis, but not ppET-1 mRNA levels, stimulated by ANG II. ANG II receptor antagonist (DuP 753), on the other hand, inhibited protein synthesis stimulated by ANG II, but not by ET-1, indicating the specificity of each receptor antagonist. Our results of ANG II-stimulated ppET-1 mRNA and ET-1 release coupled with the inhibitory effect of ETA receptor antagonist on ANG II-induced protein synthesis suggest that endogenous ET-1 stimulated by ANG II act as an autocrine/paracrine factor through ETA receptor.

Recent studies have revealed that specific inhibitory action in mRNA by antisense oligonucleotides is a useful tool in molecular and cellular biology, because it can be used in principle to determine the role played by any given gene in living cells. It is generally accepted that the selective blocking action on target mRNA by oligonucleotides is caused by $\mathrm{RNase}-\mathrm{H}$-induced cleavage of the mRNA in the mRNA-oligonucleotide hybrid, although possible mechanisms at transcriptional and/or post- 
transcriptional level may be involved (see the review of Helene and Toulme, reference 30). Although the antisense oligonucleotide used in this study was sensitive to endonuclease, the dose $\left(10^{-5} \mathrm{M}\right)$ used was two orders greater than the effective dose of the endonuclease sensitive (31), thus providing enough, even in the presence of $1 \%$ serum. Our results that the antisense sequence, but not the mismatch sequence, against ppET-1 mRNA blocked ANG II-induced protein synthesis lend strong support to the potential contribution of endogenous ET-1 to ANG II-induced cardiac hypertrophy.

In summary, our study has provided evidence that de novo synthesis and release of ET-1 by neonatal rat cardiomyocytes are stimulated by ANG II, possibly through the activation of PKC. Furthermore, our results that ANG II-induced protein synthesis was blocked by ETA receptor antagonist as well as by antisense oligonucleotides against ppET-1 mRNA, suggest the potential role of endogenous ET-1 locally produced and secreted by cardiomyocytes in the mechanism of ANG II-induced cardiac hypertrophy via an autocrine/paracrine fashion.

\section{Acknowledgments}

We thank Dr. T. Masaki and Dr. K. Webster for providing cDNAs for rat ppET-1 and GAPDH, respectively, and Drs. M. Yano and F. Ikemoto, (Central Research Laboratories, Banyu Pharmaceutical Co. Ltd.) for BQ123 and Dup753.

This study was supported in part by Grant-in-Aid for Scientific Research from the Ministry of Education, Science and Culture, Japan $(02304055,3268102,3454218,3454512,04670522)$, and funds from Uehara Memorial Foundation and Kohokai Foundation.

\section{References}

1. Yanagisawa, M., H. Kurihara, S. Kimura, Y. Tomobe, M. Kobayashi, Y. Mitsui, Y. Yazaki, K. Goto, and T. Masaki. 1988. A novel potent vasoconstrictor peptide produced by vascular endothelial cells. Nature (Lond.). 332:411-415.

2. Hirata, Y., Y. Takagi, Y. Fukuda, and F. Marumo. 1989. Endothelin is a potent mitogen for rat vascular smooth muscle cells. Atherosclerosis. 78:225-228.

3. Takuwa, N., Y. Takuwa, M. Yanagisawa, K. Yamashita, and T. Masaki. 1989. A novel vasoactive peptide endothelin stimulates mitogenesis through inositol lipid turnover in Swiss 3T3 fibroblasts. J. Biol. Chem. 264:7856-7861.

4. Ito, H., Y. Hirata, M. Hiroe, M. Tsujino, S. Adachi, T. Takamoto, M. Nitta, K. Taniguchi, and F. Marumo. 1991. Endothelin-1 induces hypertrophy with enhanced expression of muscle-specific genes in cultured neonatal rat cardiomyocytes. Circ. Res. 69:209-215.

5. Suzuki, T., H. Hoshi, and Y. Mitsui. 1990. Endothelin stimulates hypertrophy and contractility of neonatal rat cardiac myocytes in a serum-free medium. FEBS (Fed. Eur. Biochem. Soc.) Lett. 268:149-151.

6. Shubeita, H. E., P. M. McDonough, A. N. Harris, K. U. Knowlton, C. C. Glembotski, J. H. Brown, and K. R. Chien. 1990. Endothelin induction of inositol phospholipid hydrolysis, sarcomere assembly, and cardiac gene expression in ventricular myocytes. A paracrine mechanism for myocardial cell hypertrophy. J. Biol. Chem. 265:20555-20562.

7. Hahn, A. W., T. J. Resink, B. T. Scott, J. Powell, Y. Dohi, and F. R. Buhler 1990. Stimulation of endothelin mRNA and secretion in rat vascular smooth muscle cells: a novel autocrine function. Cell Regul. 1:649-659.

8. Ohta, K., Y. Hirata, T. Imai, K. Kanno, T. Emori, M. Shichiri, and F. Marumo. 1990. Cytokine-induced release of endothelin-1 from porcine renal epithelial cell line. Biochem. Biophys. Res. Commun. 169:578-584.

9. Sakamoto, H., S. Sasaki, Y. Hirata, T. Imai, K. Ando, T. Ida, T. Sakurai, M.
Yanagisawa, T. Masaki, and F. Marumo. 1990. Production of endothelin-1 by rat cultured mesangial cells. Biochem. Biophys. Res. Commun. 169:462-468.

10. Shichiri, M., Y. Hirata, T. Nakajima, K. Ando, T. Imai, M. Yanagisawa, T. Masaki, and F. Marumo. 1991. Endothelin-1 is an autocrine/paracrine growth factor for human cancer cell lines. J. Clin. Invest. 87:1867-1871.

11. Sakurai, T., M. Yanagisawa, A. Inoue, U. Ryan, S. Kimura, Y. Mitui, K. Goto, and T. Masaki. 1991. cDNA cloning analysis and tissue distribution of rat preproendothelin-1 mRNA. Biochem. Biophys. Res. Commun. 175:44-47.

12. Baker, K. M., and J. F. Aceto. 1990. Angiotensin II stimulation of protein synthesis and cell growth in chick heart cells. Am. J. Physiol. 259:H610-H618.

13. Khairallah, P. A., A. L. Robertson, and D. Davila. 1972. Effects of angiotensin II on DNA, RNA and protein synthesis. In J. Genest and R. Koiw, editors. Springer-Verlag, New York Inc., NY. 212-220.

14. Ihara, M., K. Noguchi, T. Saeki, T. Fukuroda, S. Tsuchida, S. Kimura, T. Fukami, K. Ishikawa, M. Nishikabe, and M. Yano. 1992. Biological profiles of highly potent novel endothelin antagonists selective for the ETA receptor. Life Sci. 50:247-255.

15. Lee, R. J. 1991. Nonpeptide angiotensin II receptor antagonists. Am. J. Hypertens. 4:271S-272S.

16. Simpson, P., and S. Savion. 1982. Differentiation of rat myocytes in single cell cultures with and without proliferation nonmyocardial cells. Circ. Res. 50:101-116.

17. Ito, H., S. C. Miller, M. E. Billingham, H. Akimoto, S. Torti, R. Wade, R. Gahlmann, G. Lyons, L. Kedes, and F. M. Torti. 1990. Doxorubicin selectively inhibits muscle gene expression in cardiac muscle cells in vitro and in vivo. Proc. Natl. Acad. Sci. USA. 87:4275-4279.

18. Chirgwin, J. M., A. E. Przybyla, R. J. MacDonald, and W. J. Rutter. 1979 Isolation of biologically active ribonucleic acid from sources enriched in ribonuclease. Biochemistry. 18:5294-5299.

19. Feinberg, A. P., and B. A. Vogelstein. 1983. Technique for radiolabeling DNA restriction endonuclease fragments to high specific activity. Anal. Biochem. 132:6-13.

20. Ohta, K., Y. Hirata, M. Shichiri, K. Kanno, T. Emori, K. Tomita, and F. Marumo. 1991. Urinary excretion of endothelin-1 in normal subjects and patients with renal disease. Kidney Int. 39:307-311.

21. Fujii, Y., J. E. Moreira, C. Orlando, M. Maggi, G. D. Aurbach, M. L. Brandi, and K. Sakaguchi. 1991. Endothelin as an autocrine factor in the regulation of parathyroid cells. Proc. Natl. Acad. Sci. USA. 88:4235-4239.

22. Inoue, A., M. Yanagisawa, Y. Takuwa, Y. Mitsui, M. Kobayashi, and T Masaki. 1989. The human preproendothelin-1 gene. Complete nucleotide sequence and regulation of expression. J. Biol. Chem. 264:14954-14959.

23. Lee, W., P. Mitchell, and R. Tjian. 1987. Purified transcription factor AP-1 interacts with TPA-inducible enhancer elements. Cell. 49:741-752.

24. Rauchrer III, F., P. Cohen, and T. Curran. 1988. Fos-associated protein p39 is the product of the jun proto-oncogene. Science (Wash. DC). 1988:10101016.

25. Katoh, Y., I. Komuro, Y. Shibasaki, H. Yamaguchi, and Y. Yazaki. 1989. Angiotensin II induces hypertrophy and oncogene expression in cultured rat heart myocytes. Circulation. 80:II-450.

26. Yanagisawa, M., A. Inoue, Y. Takuwa, Y. Mitsui, M. Kobayashi, and T. Masaki. 1989. The human preproentothelin-1 gene: possible regulation by endothelial phosphoinositide turnover signaling. Cardiovasc. Pharmacol. 13:S13-S17.

27. Imai, T., Y. Hirata, T. Emori, M. Yanagisawa, T. Masaki, and F. Marumo. 1992. Induction of endothelin-1 gene by angiotensin and vasopressin in endothelial cells. Hypertension (Dallas). 19:753-757.

28. Emori, T., Y. Hirata, K. Ohta, M. Shichiri, K. Shimokado, and F. Marumo. 1989. Concomitant secretion of big endothelin and its C-terminal fragment from human and bovine endothelial cells. Biochem. Biophys. Res. Commun. 162:217-223.

29. Hirata, Y., H. Yoshimi, S. Takaichi, M. Yanagisawa, and T. Masaki. 1988. Binding and receptor down-regulation of a novel vasoconstrictor endothelin in cultured rat vascular smooth muscle cells. FEBS (Fed. Eur. Biochem. Soc.) Lett. 239:13-17.

30. Helene, C., and J. J. Toulme. 1990. Specific regulation of gene expression by antisense and antigene nucleic acids. Biochim. Biophys. Acta. 1049:99-125.

31. Neyses, L., J. Nouskas, and H. Vetter. 1991. Inhibition of endothelin-1 induced myocardial protein synthesis by an antisense oligonucleotide against the early growth response gene-1. Biochem. Biophys. Res. Commun. 181:22-27. 